\title{
About vozho, the Spirit of Transition Time and Formation of Holiness among Udmurt and Komi
}

\author{
Aado Lintrop \\ e-mail: aado@folklore.ee
}

\begin{abstract}
This article concentrates on one very central character in Udmurt mythology. It is a character typical of the transitional time around the solstices, an ambiguous and liminal time, which requires particular caution from the humans to protect themselves from dangerous interference from the world beyond. This character, whose name, vozho, appears in the Udmurt name of these periods, vozhodyr, the time of vozho for the winter solstice and invozho, heaven-vozho for the summer solstice, is also a water spirit. I reflect also on other water spirits and on their peculiarities. This analysis leads me to reflect on the origin and the ramifications of the concept behind vozho with its linguistic correlations, the way it is articulated and how it sheds light on the concept of holy in the Permic languages and for the Permians, Udmurt and Komi. This leads me to reflect on the correlations between liminality and holiness, the liminal places and spaces and their value, and the particular characters in the mummery festivities that characterise this transitional winter time and which are connected both to the spirits of the other world and to the dead ancestors, who are among the main providers of well-being in the Udmurt world.
\end{abstract}

Keywords: liminal period, liminal places, Permian mythology, solstices, transitional time, vozho, water spirit 


\section{Introduction}

Having set out to study the Udmurt mythology I was amazed by how little attention has been given in modern folklore studies to a supernatural creature that I consider extremely intriguing. This creature is vozho, a water-related being who is widely discussed in the studies of Udmurt folk belief made by the late $19^{\text {th }}$ century and early $20^{\text {th }}$ century authors. ${ }^{1}$ Vladimir Vladykin's fundamental treatment of Udmurt mythology discusses vozho in connection with the popular calendar, mentioning that the winter solstice period ends with a ritual called Yö vyle sulton. ${ }^{2}$ The common belief associated with this ritual was that "this day all the filth or impurity - vozhoos ${ }^{3}$ - goes under water" (Vladykin 1994: 229). Tatiana Vladykina touches upon vozho in her monograph on genre issues in connection with genre names and mumming (Vladykina 1998: $11,14,53-55,84)$. The only author who has written singularly on vozho is Irina Pletneva, who has briefly summarised everything written on the subject (Pletneva 1999). In his article on supernatural creatures connected to Udmurt buildings, Ranus Sadikov writes: "Several peoples have believed that at a certain period of time the saunas will be inhabited by spirits closely associated with water. The Komi-Permyak, for example, believed that kul'piyannez ${ }^{4}$, or water spirits, come to the sauna to warm themselves" (Sadikov 2000: 116). For some reason he makes no reference to vozho, which was known mainly in the traditions of the northern Udmurts. In December 2002 Galina Glukhova defended her doctor's thesis (supervisor Tatiana Vladykina) on the tradition of mumming, where the author also touches upon beliefs associated with vozho (Glukhova 2002: 7-10).

Becoming further involved in the subject, it began to appear to me that vozho is something of a key figure in the evolution of religious thought among the Permian peoples. By 'evolution' I do not mean progress from a lower level, or a simpler form, to a higher 
level or to a more complex form, but a process of continuous, though very common, change of meaning to which all human concepts are subject. Now I have come to the concept of 'holy', the development of which in the Permian tradition would be incomplete without the concept of vozho. The notion 'holy', which will be discussed below, is not holy in its modern, Christian sense. Vozho enables us to take a look into the worldview of people centuries ago, when the divine and the infernal were not separated by an unsurpassable gap. And since we cannot discuss vozho separately from other water-related mythological creatures, I will first observe the Udmurt beliefs associated with water spirits.

\section{Udmurt water spirits}

For me, water spirit is a conditional common name for several water-related supernatural creatures, which are difficult, if not impossible, to distinguish. In the following I will briefly present narrative motifs associated with three mythological characters in Udmurt mythology ${ }^{5}$. In order to fully comprehend their idiosyncrasies and scope, I will compare these characters with several North European mythologies by drawing parallels with motifs from the works of Stith Thompson and Antti Aarne.

\section{Vumurt or vukuz'o (water + man; water + master)}

This mythological character is anthropomorphic and dwells in rivers (MI F212. Fairyland under water; G303.8.8. Devil lives in the water). Vumurt has a large family (MI F420.3.1. Water-spirits have family life under water). It is wealthy, heads a prosperous household and a large herd (MI F241.2.3. Faires' cattle under a lake; F420.4.8. Water-spirits have treasures under water), and 
sometimes appears either as a beautiful woman (MI F420.1.2.1. Water-maidens are of unusual beauty) or is dirty, ugly and hairy (MI F451.2.0.1. Dwarfs are ugly). Vumurt usually appears as a naked human, most often a woman (MI F420.1.6.7. Water-spirits are nude), who sits on the wheel of a water mill or on the river bank and combs her long hair (MI F420.5.3.1. Water-spirits sit on beach combing their long hair). Vumurt often visits marketplaces and fairs (MI F420.3.2.2. Water-women come to market and store), has the appearance of a regular farmer in the crowd (MI F420.1.6.1. Water spirits are dressed like people around them), but can be recognised by the coat, whose left skirt/corner is always wet (MI F420.1.7.1. Corner of water-spirits' dress is always wet).

In narratives water spirits become visible to the hero when he spreads a special ointment or liquid on his eyelids. In some variants a midwife smears her eyelids with the faeces of a water spirit's newborn child (MI F235.4.1. Fairies made visible through use of ointment; F235.4.4. Fairies made visible through use of magic water).

Some reports suggest that it was believed that vumurt had a single eye at the back of its head (ogre, the Devil), and that its fingers dropped off and could be found at river banks (oblong fingershaped stones have been called 'vumurt's fingers' - Pervukhin 1888 (1): 73; Vereshchagin 1996: 90).

Seeing a vumurt was sometimes considered an omen of illness or calamity. Vumurt may have married a human (MI F420.6.1.1. Water-man woos mortal girl). It may have drowned people (MI F420.5.2.1. Water-spirits lure mortal into water) and posed a threat to those who choose to swim at the wrong time, were not wearing crosses, etc. In a commonly known motif, a water spirit summons a midwife to his wife in labour (MI F372.1. Fairies take human midwife to attend fairy woman; F420.5.3.2. Water-spirit calls human midwife, F451.5.5. Dwarfs have human woman as midwife). The water spirit generously rewards the midwife, but the money/gold turns into coals or leaves (MI G303.21.1. Devil's money becomes ashes). 
About vozho, the Spirit of Transition Time and Formation of Holiness

Sometimes vumurt acts as a treasure bringer. This attribute relates it to the treasure-bringing goblins (kratt, puuk, para), known in the Estonian and Finnish tradition. In folk tales it is often attributed the role of an ignorant Old Heathen (MI K171.1. Deceptive crop division: above the ground, below the ground: AT 1030 Sharing crops, MI K72 Deceptive contest in carrying a horse; AT 1082 Carrying horse; MI K18. Throwing contest won by deception; AT 1063 Slinging contest).

From the viewpoint of this article the most intriguing belief was that during Yuletide vumurt came out of the water and dwelled in saunas.

\section{Vozho (meaning and etymology will be discussed below)}

Vozho dwell in water, rivers and ponds (MI G303.8.8. Devil lives in the water), but also in mills, saunas and empty houses. In some texts vozho is mentioned as the helper of a witch who lives in a river or a spring (Bogaevskiy 1890: 90-91). In this case it is sometimes seen flying through the air (MI F451.3.3.6. Dwarfs fly through air; MI G242. Witch flies through air). Bogaevskiy notes that vozho is a fire snake who flies over the sky and brings family luck (Bogaevskiy 1890: 98 treasure-bringer, cf. the Estonian treasure-bringing goblins puuk, kratt, and the Finnish para). The general belief was that vozho looked like a small hairy devil with a tail, horns and hoofs (MI F420.1.4.6. Water-spirits with horse feet; F451.2.1.1. Dwarfs are small; G303.4.1.6. Devil has horns; G303.4.5.3. Devil has horse's foot; G303.4.6. The devil's tail).

Vozhos often appear in great numbers. They come out of the water at night and dance and sing in abandoned houses and water mills (dancing fairies, witches, devils). They fear the cock's crow (MI F383.4. Fairy must leave at cock-crow; F420.3.4.2. Water-spirits must be in water before dawn; G303.16.19.4. Devil (Satan) flees when cock is made to crow). They may drag a human not wearing a cross into the 
water (MI F451.5.9.1. Dwarfs fear the cross; G303.16.3 Devil's power avoided by the cross). During yuletide they came to the villages, dwelled in saunas and played evil tricks at humans (MI F451.5.2.7. Dwarfs play pranks; F451.5.2.10. Dwarfs frighten mortals).

\section{Munchokuz'o (sauna + master), munchomurt (sauna + man), töd'y murt (white + man)}

A sauna fairy naturally dwells in the sauna. It usually appears as an old man clad in white (MI F236.1.3. Fairies in white clothes; F451.2.7.4. Dwarfs clad in white). In some regions it was believed to have long hair and one eye. The southern Udmurt imagined munchokuz'o as a small hairy creature. Trans-Kama Udmurts called the spirit inhabiting saunas kuz'yyrs' $i$ (the one with long hair; Sadikov 2000: 116). In some regions it was believed that saunas were inhabited by a multitude of spirits who dance and sing at night (ibid.: 115). Sauna spirits/fairies also play tricks on humans, and may even exchange a child (MI F321.1. Changeling; F420.5.2.4. Water-spirits steal children and leave changeling; G303.9.9.4. Devil takes an unbaptised child out of the cradle and lays a wooden log in its place).

We can distinguish between three main types of motif associated with water spirits:

(i) Motifs associated with water spirit, fairy and dwarf lore;

(ii) Motifs associated with the Devil and ignorant Old Heathen;

(iii) Motifs related to helpers/henchmen of the Devil (witches, vampires, treasure-bringers). 
About vozho, the Spirit of Transition Time and Formation of Holiness

\section{The semantic meaning and associations of the word vozho}

The semantic field of the Old Permian word vezha enabled its use as an equivalent for the Christian concept 'holy'/'sacred': yyen vezha lov, holy spirit; vezha kuima, Holy Trinity; vezha lun, holy day (Sunday) (Lytkin 1952: 156). In Modern Komi vezh also means 'holy'/'sacred', but also 'cross': vezha va, holy water; vezhay, godfather (holy / cross father); vezhan, godmother. Vezhadyr means Yuletide (Russian svyatki), but the Komi-Zyryan vezha also means 'filthy'/'impure' and 'the Devil' (Gribova 1975: 110). The verb vezhny means 'exchange', vezhöm was the child exchanged by the Devil or an evil spirit in Komi mythology. In the Udmurt language vozho does not directly mean 'holy', this particular meaning becomes evident in connection with Yuletide, called vozhodyr among the Udmurt, as well as the Komi. The Udmurt have a different name for its summer counterpart, invozho $d y r$ (sky + vozho + time/tide). The vozhos are the previously-described demonic spirits. The word vozh, closely related to vozho, means 'green', 'verdure', 'unripe' in the Udmurt language. In the expression 'vozhde en vay' (don't be angry / don't bear a grudge!) it means 'anger'. The words vozhomyny (vozho + to go) 'get excited/heated' and vozhpoton (vozh + will/wish/ feeling) 'anger' appear to derive from the same root. Interestingly, the Finnish words viha, vihainen 'anger', 'angry' and vihannuus, vihannoida 'green', 'to turn green' seem to share a common root. Michael Agricola and Jacobus Finno have used the words wihleinen, wihileijnen, wihileitzet, wiheliaidzexi in the sense 'bad', 'vile', 'weak', 'impure/filthy', 'deceitful/dishonourable', 'faulty/spiteful' (SKES VI 1735). Such words from the Estonian mythology like maaviha, küüneviha, perhaps also humalaviha may derive from the negative force emanating from these objects (earth, nail, hops). 
On the one hand the semantic field of the word vozho seems to approach the concept 'holy/sacred' and on the other hand it can be associated with notions 'anger', 'green', 'evil' and 'impure'.

It is likely that such an extended form of the semantic field may have originated from two different roots. The first could be associated with liminality, or existing somewhere in-between: *vayesh > Early Permian vezh-> Udm. vozh 'crossroad', 'river mouth', 'either of two warps', 'the crossing of warps and woofs', cf. vozhen-vozhen 'alternatively', vozhmin 'in turns', perhaps also invozh (sky + vozh) 'horizon'; Komi vezh, vizh - tuy-vezh 'crossroad', vezhny 'change'; Finnish vaihe, Estonian vahe 'difference', 'interval', 'gap' (SKES V: 1592-1593).

Finnish linguists have speculated on the relation of the Finnish vaihe and the Permyak vezh-, but had they been acquainted with Udmurt or Komi mythology this would not have been mere speculation. In the Komi compound and its Udmurt equivalent the first component signified liminality, the solstitial period, or the extraordinary transition period between two ordinary periods.

The second root was associated with the colour green, bitter taste and strong emotions (like anger and lust): *visha $>$ East Mordvin ozho 'yellow'; Cheremis (zhar, zhar, Eastern Mari uzhar 'green', 'young', 'unripe'; Udm. vozh 'green', 'unripe', 'small', 'anger', 'fury'; Komi vezh 'green', 'yellow', 'envy', 'lust'. Cf. Finnish viha, vihainen, vihannuus, Old Hindi visám 'poison', Avestan visha - vish zairitəm 'greenish poisonous liquid', Pahlavi wish 'poison', 'bile', 'spiteful', etc. (SKES VI: 1734). In time the two roots approached each other and their meanings may have overlapped. An attempt to interpret the word vozhodyr as 'becoming angry or furious' occurs in earlier studies on Udmurt mythology. 
About vozho, the Spirit of Transition Time and Formation of Holiness

\section{Liminality of crossroads and river mouth}

Crossroads and river mouths, places between two water bodies or roads, are certainly liminal places. In his short monograph The Crossroad in Folklore and Myth Martin Puhvel studies beliefs associated with crossroads in many traditions throughout history (Puhvel 1989). Interestingly enough, he does not mention liminality as the main characteristic of crossroads, although he presents numerous examples of how it was believed that homeless/restless/ placeless spirits gather in these particular places. In the mythologies of several Siberian peoples, a specific water body (river, lake) was associated with a specific supernatural creature, which functioned as a master/fairy of the body of water. Among the Ob-Ugrians these spiritual beings were related according to a complex system, such as in the narrative about the Old Man of the Ob and the Fairy of the Salym River, recorded by Anzori Barkalaja:

As-iki is the master of fish. He makes fish and sends them into the nets of the fishermen. He also decides how many fish must go into each river. Once it so happened that the god of Salym [a tributary of Ob. The god of Salym is master of thunder and notorious for his bellicose disposition - A. Barkalaja] thought he was getting too few fish from As-iki. So up he goes to As-iki and demands: "Listen, why do you give me so few fish, give me more." But As-iki was in a defiant mood, did not give him fish. So the god of Salym went away and began to prepare for war. He picked up an arrow-shaft and began to whittle away on it. Whittled one chip off it - the chip turned into a stickle-back. Whittled another chip - that, too, turned into a stickle-back. Thus the stickle-backs became many. They swam downstream into the river Ob. As-iki looks - a stickle-back. Looks again - nu, holera, (emotional interjection in Russian, translates as "Oh, cholera!") another 
stickle-back! So he went upstream along the Ob until he could see - the Old Man of Salym is whittling away at arrow-shafts, chips are falling down and turning into stickle-backs. As-iki got a terrible fright, began to call from afar: "What are you doing there, planning to wage war? Against whom?" Salymiki called back: "Against you, of course, why don't you give me fish?!" So As-iki reckoned the matter was grave and sent lots of fish into the Salym, many large pikes. Hmh. (Barkalaja 1999: 69 > Semyon Pesikov, Lyamin, 1993).

The estuaries of rivers can then be regarded as territories between the domains of two similar supernatural creatures. Analogous beliefs are known about crossroads. Puhvel's examples on the inability of supernatural creatures to cross crossroads (Puhvel 1989: 97-98) seem to indicate as much. The liminality of crossroads is also emphasised by the association of various initiation rites and solstitial traditions connected with crossroads. The Awemba tribe in northern Zambia, for example, conducted ritual purification of young girls at puberty at crossroads (ibid.: 73), in some parts of Europe (for example France, northern Sweden) the midsummer fires were lit at crossroads (ibid.: 75). Among many peoples, including the Estonians and the Udmurts, it was customary to perform various magical actions, especially foretelling, at crossroads.

\section{Holy periods}

Human lives and calendar years contain interim periods, characterised by indefiniteness due to a lack of boundary. These periods are exposed to good and evil and are close to praeternatural. The boundaries are a part of our system of orientation. With no limits the space would be homogeneous: there would be no difference between familiar and unfamiliar, good and bad, sacred and profane places. The same applies to time. Expressions like good times, bad 
times, difficult times, mad times, fast times, holidays, common days, childhood, youth, manhood, etc., clearly express evaluation and definition of limits. Transitions from one period, one stage of life, or one condition to another are like crossroads or partings of ways in time. When liminality renders the ordinary orientation dysfunctional, ordinary behaviour will become ineffective or inappropriate. Different times need different behaviour. This is why people have carried out various practices related to liminal conditions and periods and analytically called them rites of passage throughout history.

\section{Holy time in the Udmurt popular calendar}

Several restrictions were established for the summer and winter vozho period:

The Votyaks of Glazov county still hold the belief that during the vozho period it is forbidden to make noise, especially near a body of water: this is why people do not swim, or play singing games, or do the laundry in or near bodies of water in summer. In winter people do not do laundry in the river and avoid singing when crossing a bridge. During this winter period it is also forbidden to put out embers, like those falling from burning chips, by stomping... In the Gyya, Lyp and Polom parishes the period of vozho was associated with the blooming of rye. ${ }^{6}$ Soiling water during this period was considered a grave sin - therefore it was forbidden to swim, wash the laundry or the dishes (even near a well), and even drive the herd into the river. These restrictions had to be followed especially around noon, when people tried to make no loud noises (Pervukhin 1888 (1): 59-60).

Harva notes that violating the restriction caused suffering for the whole community, either in the form of storm or hail storm (Harva 
1914: 174). Women in the village of Kuz'ebayevo have told the author of this paper that during the summer invozho period it was forbidden to work with wool or hemp and to mow and pick flowers. In Kuz'ebayevo this period ended on St. Peter's Day (July 12 $\left.{ }^{\text {th }}\right)$. The invozho period was often associated with the blooming of catchfly or maiden pink (invozho s'as'ka). In June 2003 some people from Varkled-Bod'ya village said: "vös', pe, voz'vyle pote invozho dyr"ya", there is saying that during the invozho period religion/belief walks in the meadows.

The winter vozho period was the main storytelling and riddling time for the Udmurt (Shklyayev 1989: 36). Even as late as in June 2002 three informants, living in Udmurtskiy-Karaul and Deby villages in the Krasnogorskoye region, claimed that the words for 'riddle' in local dialect were vozho kyl (vozho 'language/word/story') or vozho mad' (vozho 'speech/word/story') ${ }^{7}$. Even though Pervukhin assumed that the word vozho mad'could be interpreted as "the story of the winter vozho period" (Pervukhin 1888 (3): 70), and Tatiana Vladykina seems to agree (Vladykina 1988: 11), this interpretation does not seem justified. On the one hand the word vozho mad' referred to the traditional, ancestral nature of the text (cf. vyzhy kyl, 'myth', 'root/gender/tribe/generation' + 'language/word/story'), on the other hand the word might have indicated the existence of a special style for communicating with visitors at solstices, the artistic style of folk tales and riddles.

In Russian folklore the water fairy sleeps in the winter and is at the peak of its action at midsummer, from Midsummer Day $^{8}$ to St Peter's Day or to St Eliyah's Day (at the beginning of August) (Krinichnaya 1994: 19-21), i.e. during the period that the Udmurt call invozho dyr. In Russian accounts the most dangerous time for bathing and swimming was noon and midnight, but also early in the morning and late at night (ibid.: 21-22). The Votian water spirit is also active in summer (especially around the Midsummer Day). A ram was reportedly sacrificed to it at the River Lauga on St Eliyah's Day while saying: "Nahh, sü̈̈ boranaa päit, elä süü 
About vozho, the Spirit of Transition Time and Formation of Holiness

inemisii!' (There, eat ram heads, not people!) (Västrik 1999: 24, 25). We can only speculate on whether the sacrifice was supposed to symbolise the end of the water spirit's period of activity.

\section{Visitors of the liminal period}

The Udmurts of the Glazov County believed that water spirits came into the villages and inhabited the saunas before Christmas. In the twilight they could be encountered on the street:

During the summer vozho $d y r$ it sleeps, but on the winter solstice (before Christmas) it leaves the water and spends most of its time in saunas, though it could be met on the street. This is why no Votyak dares to walk alone on the streets without a burnt wood chip during Christmas. (Pervukhin 1888 (1): 75).

The water spirits of the Christmas period were mainly called the vozhos. Pervukhin continues:

From December $25^{\text {th }}$ to January $6^{\text {th }}$ small (no longer than a few archines tall), colourful, though relatively similarlooking devils (with tails and horns) walk on the streets of villages, settlements, even the town of Glazov. The Russians call them kulish, the Votyaks vozho. Like water spirits, the vozho fear even the smallest piece of burnt wood.... Those who walk around without a chip, will be tripped up by the vozho.... for the same purpose they turn into a post, or the corner of a house... They might take a man to his neighbour's house instead of his own, or might make a woman drive other people's cattle to her own yard... (Pervukhin 1888 (1): 99-100). 
For the Udmurt, vozhodyr is the period for mumming. The most common name for mumming is pörtmas'kon, cf. pörtmany - 'to change', 'to transform', 'to slander'. Other words for mumming are pen'dzh'as'kon (cf. pen' 'soot', 'ashes', pen'dzh'any incinerate', 'to burn to ashes', referring to the most common way of masking by smearing the face with soot or ashes), vozhoyas'kon vozhoas'kon ('vozho-ing'; in several regions the mummers called themselves the vozho) and chokmorskon. The latter derives from the word chokmor, wooden club (cf. Russian chekmar' 'wooden club', 'beater' < cheka 'wedge', 'pole') and refers to the banging of house corners and floors with sticks and clubs, a characteristic activity of the mummers, which helped to repel evil spirits and diseases from the house and the village (Vladykin 1994: 227). The Udmurt Christmas mummers almost seem to have split personalities: the fact that they wore clothes inside out, had faces smeared with soot, men were wearing women's clothes and women were wearing men's clothes, indicates that they were visitors from the otherworld (where, according to universal belief, things are the reverse of this world). The fact that they were believed to bring luck in herding relates them to the souls of ancestors, who were universally considered the primary bringers of herding luck in many cultures. And, last but not least, the mummers were addressed as the vozho, which was undoubtedly related to the dead ancestors.

The Udmurt Christmas mummers also functioned as repellers of evil forces. Vladykin mentions an account that described how mummers ran along village streets, screaming loudly, banging against the corners of houses, and on the floors inside the houses, frightening the sauna spirits away (munchokuz'oos Vladykin 1994: 226-22), although according to a fairly commonly held belief the vozhos inhabited the saunas. As I have indicated before, no clear distinction was made between the sauna fairies and the vozhos. The exorcistic function of the Udmurt Christmas mummers very likely originates in the traditions associated with the end of the solstitial period. 
About vozho, the Spirit of Transition Time and Formation of Holiness

The winter vozho period ends on January $19^{9}$ (or the Epiphany of Jesus according to the Orthodox calendar) with a feast day called vozho kel'an 'the sending off', or 'the departure of vozho' or yö vylyn sylon 'standing on ice'. On the night before January 6 the young people of the village walked from sauna to sauna singing songs, "listened to their fate" and told the vozho: "pot tatys' mil'emesty les'?' ('leave us!'). The next morning all the men went to the river and banged on the ice with their axes and clubs, shouting "koshky tatys'?' ('leave this place!') (Pervukhin 1888 (2): 105-106).

\section{The formation of the concept 'holy' among the Permian peoples}

Considering that the word vozhodyr denoted the liminal period of the winter and summer solstices and was not a recent loan from the Russian svyatki, and considering that the vozhos were the praeternatural visitors of this period, probably related to departed ancestors, we can now reflect on the formation of the concept 'holy' among the Permians.

The solstice was a special and dangerous period, and the supernatural visitors of this period, although expected, were considered dangerous and required special treatment. The concept 'holy' was closely related to the strange, the special, the liminal, the dangerous and the desirable. Before the introduction of Christian terminology, the Permian word for such phenomena was vezh. Words derived from this root were probably used to signify places, periods, objects and creatures that required special treatment, including transitional or interim periods in calendar and geographical and territorial border areas. As the concept also comprised the sacred places for worship and cult objects, the word vezh seemed most appropriate for the Permian equivalent for the Christian concept 'holy', and Stephan of Perm soon adopted the word in Komi. Even though the Second Commandment declares "for I the Lord thy God 
am a jealous God" (Ex 20:5) and the Second Book of Moses says "for the LORD, whose name is Jealous" (Ex 34:14), the Christian concept of 'holy wrath' is less inclined to the unknown, liminal and dangerous. The supernatural visitors of the solstitial period were no longer included in the semantic field of the concept (vezh), and came to be called the Chudes.

Common conceptions about the Chudes can be divided into three major groups: (i) the Chudes were a people living on the upper course of the River Kama and the Vychegda River long before the Komi; (ii) the Chudes were the Komi before their conversion to Christianity; (iii) the Chudes were the Komi heroes (Gribova 1975: 93). The Chudes objected to the arrival of tall people. They hid themselves in saunas and holes, and threw stones and coal at the newcomers. The holes of the Chudes are still there: they probably fell down through them (ibid.: 95). They were the Komi, only unbaptised like the Chudes. When they were Christianised, they believed it was something bad and hurt themselves: they built dugouts, descended to these dugouts and severed the beams supporting the ceilings... (ibid.: 96).

The Komi also attributed the name Chudes to vozho-like creatures:

According to Komi-Permyak belief the Chudes are...small anthropomorphic black creatures who live in dark places: abandoned houses, saunas, drying barns, cellars, inside the house behind the oven and under the floor, in the woods and in water. They are, in fact, called sauna-Chudes, barn-Chudes, etc. They cause troubles for humans: they frighten them (especially at Christmas), drag them into eddies, smother them in the sauna. Sometimes they steal children and replace them with wooden logs. These children are called 'woodlogs', or vezhöm 'exchanged'. The exchange is particularly successful when the child is unbaptised or does not wear a cross around its neck. The exchanged child can eat and drink as much as it likes, but it will neither grow nor develop (Gribova 1975: 107). 
About vozho, the Spirit of Transition Time and Formation of Holiness

Regardless of the several presented etymologies tracing the origin of the word Chude to more distant languages, I tend to support the Slavic origin of the word (chudo, chudyy, ethnonym chud', which the Christianised Slavic tribes appeared to have used for heathen Finno-Ugrians). Similarly to the visitors of the liminal period, who were associated with deceased ancestors, the Christian Komi attributed the Chudes a new identity as heathen forefathers or heroes and demonised them. Several Komi folklore texts describe the demonisation of the heathen ancestors of the Christianised Komi:

The Kars ${ }^{10}$, these were the towns: Kudym Kar, Kureg Kar. People lived underground, built log houses and lived on meat and fish.... But later, when the conversion to Christianity began, they began to destroy themselves, buried themselves alive. Whoever refused to be baptised was not allowed in the house. Walked around as a Chude - small, pitiful, was afraid of everyone. These were the years of spirits - you pass the sauna, pass the river, it haunts everywhere. ${ }^{11}$ Even when doing needlework. But they would not surrender, they slept in the sauna or in the threshing barn. Even now they are called the 'sauna-Chudes' (Limerov 1998: 39).

Stephan of Perm's influence did not affect the Udmurt area, and the later coiners of Christian terminology in the Udmurt language were probably unable to see the relationship between the Udmurt vozh-/vozho and the Christian concept of 'holy/sacred'. For this reason the Udmurt do not have their own word for this and use Russian loans svyatoy and svyashchennyy (for example a recently collected modern prayer: sv'atoy Inmar, sv'atoy kulontem, mil'emly dzh'ech kar - Holy God, Holy Strong, Holy Immortal, have mercy on us (lit: do us good ${ }^{12}$ ). At the same time there was no need for the new name of visitors during the solstitial period, who continued to be known as the vozhos, and were demonised. The demonisation of analogous mythological characters, such as 'various fairies, spirits 
and dwarfs, in the mythologies of different countries is suggested by the motifs presented at the beginning of the article.

In the Permian languages the Christian concept of 'holy/sacred' was derived either from the word originally denoting the liminal, the unusual, perhaps even the impure (the Komi example), or was a loan word (the Udmurt example). The study of toponyms should reveal whether vezha and vozho were used in a religious sense. A good example from the Komi language is perhaps the KhantyMansi sacred place at the River Ob, Yem vosh / Yalp uus, the residence of the mythological Old Man of the Holy Town, which after the Komi expansion came to be called by its literal equivalent Vezhakary, or the Holy Town. Toponyms, however, will not be very useful because in the Udmurt language it is difficult to distinguish between the notions vozh ('green', 'anger') and vozho (originally 'holy'). We may speculate that the village name Vozheshur and the river name Vozhoy shur originate in the concept 'holy' rather than 'green', therefore meaning 'the Holy River', and also the village name Vozhoyka, but we cannot be absolutely certain, especially because it is clear that the village name Vozhkyr originates in the notion 'green' and has the meaning 'green woodpecker'. The Permian example enables us to explain Veikko Anttonen's argument that the concept of 'holy' is associated with impureness - his assumption was strongly misunderstood by Anzori Barkalaja in his master's thesis (Barkalaja 1996: 23). Having accused several other authors of being too "progressive", Barkalaja seems to have fallen into his own trap, as he refused to admit the possibility of the change of religious concepts in time. Like the concept of 'holy', the concept of 'filthy/impure' has definitely changed as well. In several traditional cultures objects associated with birth and death often require special treatment, for example these objects are taken into particular wood groves or other places, sanctuaries, distinct from ordinary places. A woman, who is considered impure during menstruation and in the postnatal period, requires special treatment often being isolated, either symbolically or physically, 
from the rest of the community. In Mansi villages there are specific houses called man' kol (the small house) for this purpose, where other villagers would not go. Harriet Lutzky has argued that the Latin sacer derives from the Indo-European root *sak- or *sek-, both meaning 'to cut', 'to set apart', therefore sacralised through separation (Lutzky 1993: 285-287). Emile Benveniste has argued that the Latin adjective sacer had two contradictory meanings: (a) he who belongs to the gods and (b) he who is cast out, afraid, damned. A person marked with the word sacer was considered impure and therefore a social outcast. The one given to gods (sacer) as well as the impure (sacer) signified whoever or whatever was cast/cut out of human society (Benveniste 1973: 453). This cut-off or separated object served as a bridge, doorway, threshold or path (whichever metaphor you choose) connecting the everyday world and the supernatural sphere. Even Jesus, the Son of Mary was cast out of human society in birth and in death. Particularly for this reason he was authorised to say "I am the way, the truth, and the life: no man cometh unto the Father, but by me" (Jh 14:6). According to Veikko Anttonen the two main features of the 'holy' category are anomality and liminality (Anttonen 1992: 2526). The formation of the concept 'holy' among the Permian peoples illustrates and supports Anttonen's statement. Liminality was undoubtedly an important distinguishing feature between the holy and the profane. Another example of the threshold between the two spheres are the inscriptions above church doors or gates Hic est domus Dei et porta caeli.

\section{Conclusion}

I hope the article helped to clarify why supernatural visitors related to deceased ancestors come from water and how and why are they related to water spirits in the Udmurt mythology. The answer is quite simple - according to a commonly held belief the realm of the dead is situated on the other side of water (often on an island in the 
northern sea), or it was believed that the pathway to the otherworld ran downstream beside the river. It is quite logical to believe that if the dead (or their souls) descend to the realm of the dead downstream, they will return to visit their living relatives upstream.

I am aware that the Udmurt vozhos and the Komi vezhas or Chudes have counterparts in other North Eurasian mythologies. For example, the Russian kulish $\sim$ kulyash and shulikun. The etymologies of these words are quite intriguing. Kulish and kulyash originate in the Ugrian and/or Permian languages (cf. the Mansi kul' or kul'otor 'Lord of the underworld, the Devil', Komi kul' 'water spirit, the Devil'. Shulikun or shilikun appears to be linguistically, as well as mythologically, related to the character sülü̈̈kün süllükün in Yakut mythology (speculated origin in the Old Turkic word suvluY 'water-', 'water-related'). Parallels could also be drawn with the demonic Christmas visitors of the Russians, Yakuts and Udmurts. Here I am not saying that the Russians have borrowed their solstitial visitors from the Turkic or Finno-Ugric peoples. It is highly likely that the Russians had their own word for such supernatural creatures, and the name was either abandoned or was attributed a new meaning. As to the names of St Martinmas' and St Catherine's Day's mummers (mardisandid, kadrisandid) in the Estonian tradition, the word sant ('beggar' or 'cripple' in Modern Estonian) seems to be either a similar loan for the same purposes, or was borrowed from the official language used in the contemporary liturgy with the purpose of rehabilitating the spiritual visitors in the eyes of the Church.

\section{Notes}

1 Especially by N. Pervukhin, but also by I. Vasilyev, P. Bogaevskiy.

${ }^{2}$ Literally 'standing on ice'. On the previous night the village youngsters performed a ritual called vozho kel'an 'the sending off or the departure of vozho', walking from sauna to sauna, shouting loudly, in order to repel the Vozho who had gone to live there over Christmas. 
About vozho, the Spirit of Transition Time and Formation of Holiness

3 The plural form of vozho, i.e. vozhos.

${ }^{4}$ In the Komi mythology Kul' is both the Devil and an evil water spirit. Kul'piyannez could be the diminutive form - sons/cubs of the Devil.

5 On references to the origin of the Udmurt motifs, see Lintrop 2000.

6 The motif of water sprites walking in the fields while rye was blooming is also known in Russian folklore (Krinichnaya 1994: 23).

7 The ethnic genre name for riddles, vozho mad', is mentioned in Gavrilov 1880: 54, Pervukhin 1888 (3): 70; Wichmann (1901: 6-7). Pervukhin has used the same word for folk tale. The more common modern term for riddle is mad'is'kon kyl or mad'kyl.

8 In the Yaroslavl Governorate Midsummer Day was considered the water spirit's name day (Krinichnaya 1994: 19).

9 January 6 according to the old calendar.

${ }^{10} \mathrm{Kar}$, 'town', 'township' in the Permyak language.

${ }^{11}$ Originally: 'chudlivyye ved' gody byl'i - mimo ban'i id'osh', mimo reki, tak vs'udu chud'its'a".

12 The prayer derives from the Orthodox liturgy Trisagion Svyatyy Bozhe, Suyatyy Krepkiy, suyatyy Bessmertnyy, pomiluy nas (Holy God, holy Strong, holy Immortal, have mercy on us), which in the Udmurt language is sv'atoy inmar, sv'atoy kulontem, mil'emly dzh'ech kar.

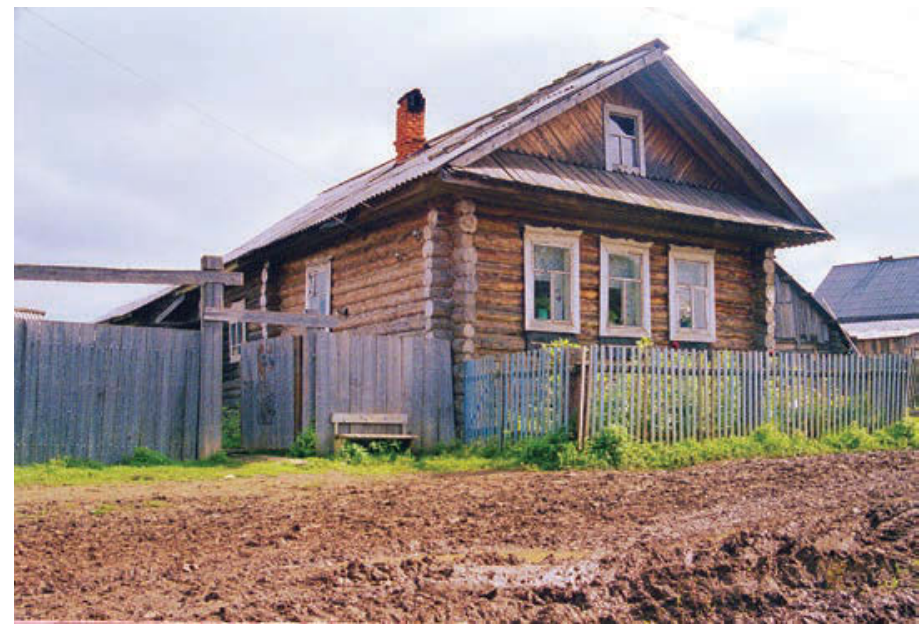

Photo 1. A Besserman village in Udmurtia. Photo by A. Kuperjanov 2000. 


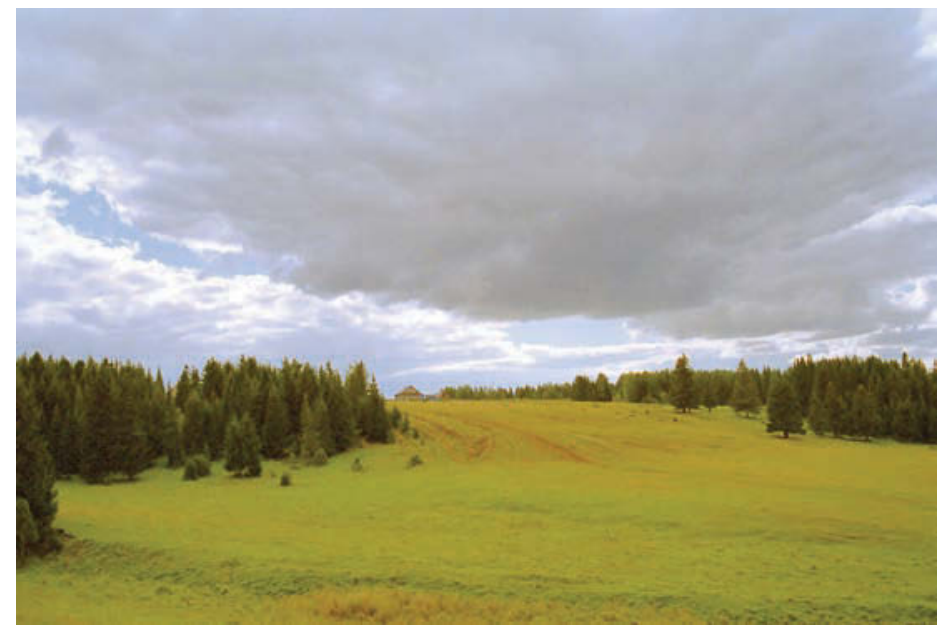

Photo 2. Northern Udmurtia landscape.

Photo by A. Kuperjanov 2000.

\section{References}

AT $=$ Aarne, A. \& Thompson, S. 1961. The Types of the Folktale. FF Communications 184. Helsinki. Academia Scientiarum fennica.

Anttonen, V. 1992. "Püha" mõiste rahvausundi uurimises [The Concept of "Holy" in Folkloristic Research]. Akadeemia 12, pp. 2514-2535.

Barkalaja, A. 1996. Handi rahvausundist, selle seostest vene oigeusu ja teadusliku mõtlemisega [About Khanty Folk Beliefs, Their Connections with Russian Orthodoxy and Scientific Thinking]. Väitekiri magistrikraadi taotlemiseks eesti rahvaluule alal. Tartu Ülikool, eesti ja võrdleva rahvaluule õppetool.

Barkalaja, A. 1999. On the Sacrificial Rituals of the Pim River Khanties: Part Two. Pro Ethnologia 8, Arctic Studies 3. Tartu, pp. 57-71.

Benveniste, E. 1973. Indo-European Language and Society. Miami Linguistics Series No. 12. University of Miami Press.

Bogaevskiy, P. 1890. Ocherki religioznykh predstavleniy udmurtov [Essay about the Religious Representations of the Udmurt]. Etnograficheskoye obozreniye, Nos. 1, 2, 4. Moskva. 
About vozho, the Spirit of Transition Time and Formation of Holiness

Gavrilov, B. 1880. Proizvedeniya narodnoy slovesnosti, obryady i pover'ya votyakov Kazanskoy i Vyatskoy guberniy [Works of folk Orality, Rituals and Beliefs of the Votyaks from the Kazan and Vyatka Governorates]. Kazan: Pravoslavnoye missionerskoye obshchestvo.

Glukhova, G. 2002. Simvolika ryazhen'ya v traditsionnoy kul'ture udmurtov [The Symbolic of Mumming in the Udmurt's Traditional Culture]. Avtoreferat dissertatsii soiskanie uchenoy stepeni kandidata filologicheskikh nauk. Izhevsk.

Gribova, L. 1975. Permskiy zverinyy stil' [The Perm' Animal Style]. Moskva: Nauka.

Holmberg, U. 1914. Permalaisten uskonto. Suomen suvun uskonnot IV. [The Permians' Religion. The Beliefs of the Finn's Kin]. Porvoo. SKS.

Krinichnaya, N. 1994. Na sinem kamne. Mifologicheskiye rasskazy i pover'ya o dukhe-"khozyaine" vody [On the Blue Stone. Mythological Tales and Beliefs about the "Master" Spirit of the Water]. Petrozavodsk: Karel'skiy nauchnyy tsentr RAN.

Limerov, P. 1998. Komi neskazochnaya proza [The Komi Non-Narrative Prose]. Syktyvkar: Izd-vo SGU.

Lintrop, A. 2000. Udmurdi usundi peamised tunnusjooned XIX ja $X X$ sajandil [The Main Features of the Udmurt Beliefs in the $19^{\text {th }}$ and $20^{\text {th }}$ Centuries]. Doktoriväitekiri. CD. Tartu.

Lutzky, H. 1993. On a Concept Underlying Indo-European Terms for the Sacred. The Journal of Indo-European Studies 21, pp. 283-301.

Lytkin, V. 1952. Drevnepermskiy yazyk [The Old Permian Language]. Moskva: Izdatel'stvo Akademii Nauk SSSR.

MI = Thompson, S. 1932-1936. Motif-Index of Folk-Literature. FF Communications 106-109, 116, 117. Helsinki.

Pervukhin, N. 1888. Eskizy predaniy i byta inorodtsev Glazovskogo uyezda [Essays about the Legends and the Everyday Life of Non-Russians of the Glazov District]. Eskiz 1, Eskiz 2, Eskiz 3 [Essay 1, Essay 2, Essay 3]. Vyatka: Gubernskaya tipografiya.

Pletneva, I. 1999. K semantike udmurtskogo vozho. Problemy udmurtskoy i finno-ugorskoy filologii: Mezhvuzovskiy sbornik nauchnykh trudov [About the Semantics of Vozho. Problems of Udmurt and Finno-Ugric Philology. University Collection of Scientific Works]. Izhevsk: Udmurtskiy universitet, kafedra obshchego i finno-ugorskogo yazykoznaniya.

Puhvel, M. 1989. The Crossroads in Folklore and Myth. American University Studies. Series IV, English Language and Literature. Vol. 88. New York. 
Sadikov, R. 2000. Kaama-taguste udmurtide ettekujutused elamu kaitsevaimudest [The Trans-Kama Udmurt's Representations of the Home Protective Spirits]. Mäetagused 13, pp. 112-118.

SKES 1975, 1978. Suomen kielen etymologinen sanakirja [The Etymology dictionary of Finnish]. V, VI, Helsinki. SUS.

Shklyayev, G. 1989. Obryady i pover'ya udmurtov, svyazannyye s zhilishchem [Rituals and Beliefs of the Udmurt about Dwellings]. Fol'klor i etnografiya udmurtov: obryady, obychai, pover'ya [Udmurt Folklore and Ethnography: Rituals, Customs, Beliefs]. Izhevsk: Udmurtskiy institut istorii, yazyka i literatury Uralskogo otdeleniya Rossiyskoy akademii nauk, pp. 28-43.

Vereshchagin, G. 1996. Votyaki Sarapul'skogo uyezda Vyatskoy gubernii. [The Votyaks of the Sarapul District of the Vyatka Governorate]. Sobraniye sochineniy, t. 2. Izhevsk: Udmurtskiy institut istorii, yazyka i literatury Uralskogo otdeleniya Rossiyskoy akademii nauk.

Vladykin, V. 1994. Religiozno-mifologicheskaya kartina mira udmurtov The Udmurt's Religious and Mythological Worldview]. Izhevsk: Udmurtia.

Vladykina, T. 1998. Udmurtskiy fol'klor. Problemy zhanrovoy evolyutsii $i$ sistematiki [The Udmurt Folklore. Problems of Genre Evolution and Systematisation]. Izhevsk: Udmurtskiy institut istorii, yazyka i literatury Uralskogo otdeleniya Rossiyskoy akademii nauk.

Västrik, E.-H. 1999. The Waters and Water Spirits in Votian Folk Belief. Folklore, Vol. 12, pp. 16-37.

Wichmann, Y. 1901. Wotjakische Chrestomatie mit Glossar. Helsingfors. Finnische-Ugrische Gesellschaft.

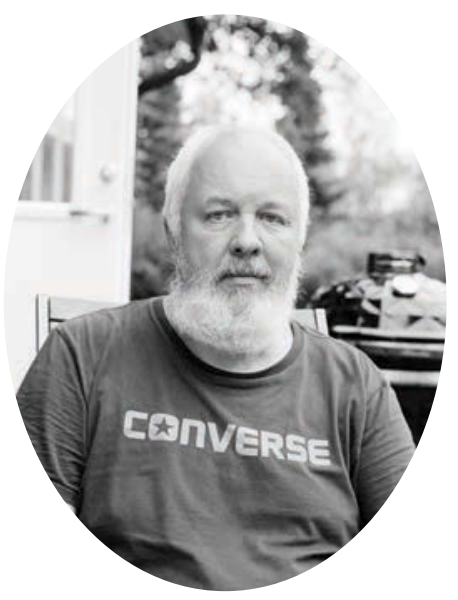

Aado Lintrop ( $\mathrm{PhD}$ ) is a senior researcher at the Estonian Folklore Archives of the Estonian Literary Museum, Estonia. He is interested in Ob-Ugrian mythology and folklore as well as in Udmurt mythology and traditional religion.

e-mail: aado@folklore.ee 